REVIEW

\title{
Review of pramlintide as adjunctive therapy in treatment of type I and type 2 diabetes
}

\author{
Gina Ryan \\ Tim A Briscoe \\ Lynette Jobe
}

College of Pharmacy and Health Sciences, Mercer University, Atlanta, Georgia, USA

\begin{abstract}
Pramlintide $\left(\operatorname{Symlin}^{\circledR}\right)$, a synthetic analog of a neurohormone amylin, was approved by the US Food and Drug Administration for use along with premeal insulin in patients with type 1 . In patients with type 2 diabetes, pramlintide is approved for addition to premeal insulin in those patients who are either only on premeal insulin or those receiving the combination of insulin and metformin and/or a sulfonylurea. This article reviews the pharmacology, pharmacokinetics, dosing, clinical trials, safety, contraindications, and drug interactions of pramlintide therapy. A search for published clinical trials and therapeutic reviews in the English language was done in the following databases: Iowa Drug Information Service (1966 to July 2008), MEDLINE (1966 to July 2008), and International Pharmaceutical Abstracts (1970 to July 2008). Pramlintide and amylin were used as keywords and title words. References of key articles were also reviewed to identify additional publications. Amylin is a 37 amino acid peptide neurohormone cosecreted from the beta cells of the pancreas, along with insulin, in response to meals. Amylin lowers serum glucose by decreasing glucagon release, slowing gastric emptying and decreasing food intake. Pramlintide, a synthetic analog of amylin, reduces 2-hour postprandial blood glucose between 3.4 and $5 \mathrm{mmol} / \mathrm{L}$, reduces $\mathrm{A} 1 \mathrm{C}$ by $0.2 \%$ to $0.7 \%$ and has no effect on fasting glucose levels. The use of pramlintide was associated with up to a $1.6 \mathrm{~kg}$ weight loss. Nausea was the most commonly reported adverse event. Pramlintide is an amylin analog that was FDA approved for the treatment of type 1 and type 2 diabetes. Its use results in modest reduction of A1C and the most frequent side effects are hypoglycemia and nausea.
\end{abstract}

Keywords: pramlintide, type 1 diabetes, type 2 diabetes, amylin

\section{Introduction}

Currently, 23.6 million Americans have diabetes and the number is expected to increase to 29 million by the year 2050 (National Institute of Diabetes and Digestive and Kidney Disease 2008) (Boyle et al 2001). The economic burden of diabetes in 2007 in the United States was estimated to be US\$174 billion (American Diabetes Association 2008). Type 1 diabetes is cause by an autoimmune destruction of the beta cells of the pancreas and affects about $10 \%$ of patients with diabetes (American Diabetes Association 2005). Until recently, insulin was the only pharmacotherapy for type 1 diabetes. Insulin resistance and relative insulin deficiency are the causes of type 2 diabetes, which accounts for $90 \%$ of patients with diabetes (American Diabetes Association 2005). In type 2 diabetes, the beta cells of the pancreas are typically still functioning, but they are not producing enough insulin to result in euglycemia. Insulin, sulfonylureas, metformin, glinides, alpha glucosidase inhibitors, incretin mimetics, and thiazolidinediones are used to reduce blood glucose in patients with type 2 diabetes. Glycemic control has proven to reduce the complications of type 1 and type 2 diabetes (Diabetes Control and Complication Research Trial Group 1993; United Kingdom Prospective Diabetes Study, 1998a, b; Boyle et al 2001) However, despite the availability of multiple agents, $44.5 \%$ of patients with diabetes fail to meet the American Diabetes Association's glycemic goals (Hoerger et al 2008). 
The physiology of glucose homeostasis is complex and insulin and oral agents only correct part of the pathophysiology of diabetes. Additional hormones are now being recognized for playing a vital role in glucose regulation.

Amylin is a neurohormone that is cosecreted with insulin from the beta cells of the pancreas, and its concentrations are abnormally low in patients with diabetes (Koda et al 1992). Pramlintide $\left(\operatorname{Symlin}^{\circledR}\right)$ is a synthetic analog of amylin that was approved in April 2004 by the US Food and Drug Administration (FDA) for addition to mealtime insulin therapy in patients with type 1 and type 2 diabetes. In patients with type 2 diabetes, it is also approved for use in combination with mealtime insulin with concurrent use of metformin and or a sulfonylurea. This paper will review the chemistry and preclinical pharmacology, clinical pharmacokinetics, clinical trials, safety and tolerability, contraindications, and drug interactions of pramlintide in the treatment of type 1 and type 2 diabetes.

\section{Chemistry and preclinical pharmacology}

Pramlintide is a synthetic analog of amylin. Amylin is a 37 amino acid peptide neurohormone that is cosecreted from the beta cells of the pancreas along with insulin in response to meals (Cooper et al 1987; Koda et al 1992). Amylin levels are virtually zero in patients with type 1 diabetes. Patients with type 2 diabetes have elevated levels of amylin, but relative amylin deficiency compared with normal subjects. This means that at similar levels of glucose, less amylin is secreted in patients with type 2 diabetes compared with subjects without diabetes (Koda et al 1992).

Radioligand binding studies have identified high affinity amylin receptors in distinct areas of the brain. Specifically, the greatest density of amylin receptors are located in the nucleus accumbens (NA) and the dorsal vagal complex (DVC), which is composed of the caudal portion of the nucleus tractus solitarius, also called the area postrema, and dorsal motor nucleus of the vagus (Beaumont et al 1993; Sexton et al 1994). These nuclei process primary vagal afferent input from the gastrointestinal tract and provide parasympathetic motor innervations back to the gastrointestinal tract. Activation of neuronal amylin receptors of the NA and DVC reduces food intake and depresses gastrointestinal motility (Lutz et al 2001; Grabauska et al 2004). Amylin binds to sites in pancreatic beta cells that may provide negative feedback inhibition of its own secretion and inhibits insulin release (Martinez et al 2000). Amylin suppresses postprandial glucagon from the alpha cells of the pancreas by a neuroendocrine pathway that is not completely understood (Weyer et al 2001). Suppressed gastrointestinal motility and reduced glucagon release slow the rate of glucose influx into the circulation, resulting in lower postprandial glucose levels (Figure 1). Exogenous amylin is not suitable for pharmacologic use because it aggregates into an insoluble compound. Substituting proline for the Ala-25, Ser-28, and Ser-29 of amylin results in pramlintide, a soluble, stable synthetic analog that is suitable for pharmacologic use (Pittner et al 1994).

Pramlintide decreases postprandial glucagon release and slows gastric emptying in patients with type 1 and type 2 diabetes (Kong et al 1997, 1998; Fineman et al 2002a, b). In combination with insulin, pramlintide reduces postprandial glucose in patients with type 1 or type 2 diabetes without increasing insulin levels (Kong et al 1997; Thompson et al 1997a, c; Weyer et al 2003; Maggs et al 2004). In patients with type 1 diabetes, it reduces one-hour postprandial glucose by $5-7 \mathrm{mmol} / \mathrm{L}$ and 2-hour postprandial glucose by 3.6 to $5 \mathrm{mmol} / \mathrm{L}$. In patients with type 2 , pramlintide reduces onehour and two-hour postprandial glucose between 4.8 and $6 \mathrm{mmol} / \mathrm{L}$ and 2.5 and $5 \mathrm{mmol} / \mathrm{L}$, respectively (Table 1).

\section{Clinical pharmacokinetics}

Pramlintide acetate is a clear, colorless $600 \mu \mathrm{g} / \mathrm{mL}$ solution that is buffered to a pH of 4.0. Pramlintide is available in both vials for injections and as pen injector. To reduce the potential for dosing errors, patients using a vial and insulin syringe for administration should measure their dose in units rather than micrograms or milliliters. For example, patients on $30 \mu \mathrm{g}$ of pramlintide should be instructed to measure 5 units rather than $0.05 \mathrm{~mL}$ (Table 2). Pramlintide is also available in a pen that has precalibrated doses that allows the patient to dial the dose in micrograms. The manufacturer will stop producing the vials in 2011 and solely produce the pen, which is precalibrated to deliver doses thus eliminating the need for unit conversion. In patients with type 1 diabetes, $15 \mu \mathrm{g}$ before each meal is the recommended starting dose. After 3 to 7 days of therapy the dose can be increased to $45 \mu \mathrm{g}$, then $60 \mathrm{mcg}$ as tolerated if glycemic targets are not reached. Patients with type 2 diabetes start with a $60 \mu \mathrm{g}$ dose and may be titrated to $120 \mu \mathrm{g}$ after 3 to 7 days. The time to maximum concentration is approximately 20 minutes and the half life is 29 minutes. Pramlintide is primarily eliminated via the kidneys. Dose adjustment is not required in elderly patients or patients with moderate to severe renal disease (creatinine clearance $20-50 \mathrm{~mL} / \mathrm{min}$ ). There are no data available on the safety in patients on dialysis or with end-stage renal disease. Drug accumulation is not anticipated in hepatic dysfunction (Symlin ${ }^{\circledR}$ Package Insert 2007). 


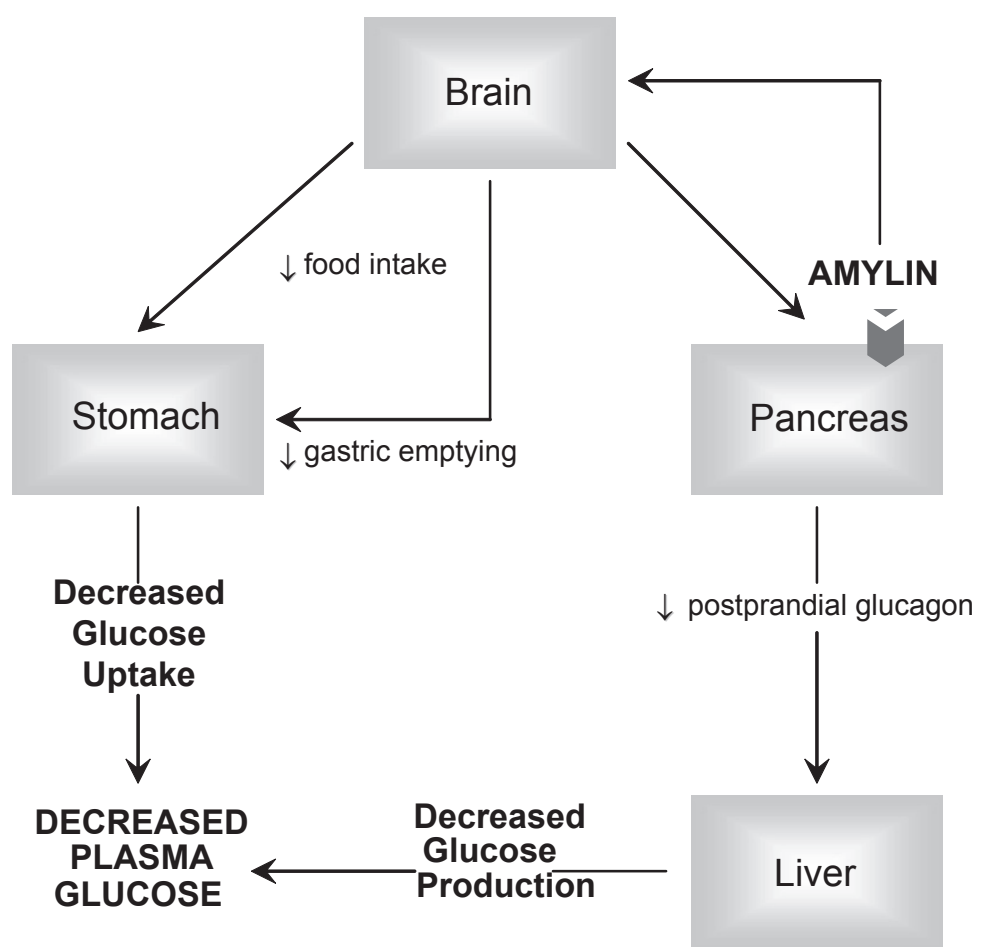

Figure I Amylin actions. The figure illustrates the three primary mechanisms by which amylin lowers serum glucose. Amylin activates receptors in the brain which sends signals via the vagus nerve to slow gastric emptying and decrease food intake. Amylin's neuronal stimulation decreases glucagon production from the pancreas alpha cells.

\section{Drug interactions}

Since pramlintide is buffered to a $\mathrm{pH}$ of 4.0 it should be incompatible with most insulin products because they are buffered to a $\mathrm{pH}$ of 7.8. However, in one study, mixing Novolin ${ }^{\circledR}$ and Humulin ${ }^{\circledR}$ brands of regular and isophane insulins with pramlintide did not affect the pharmacokinetics or efficacy of insulin or pramlintide (Weyer et al 2005). Despite these results, the pramlintide manufacturer recommends not mixing insulin and pramlintide in the same syringe (Symlin ${ }^{\circledR}$ Package Insert 2007). Pramlintide will impair the efficacy of agents that stimulate gastric motility. It slows the absorption of acetaminophen but does not affect the total amount absorbed (Kellmeyer et al 2007). The manufacture recommends separating the administration of analgesics by one hour before or two hours after administration of pramlintide to prevent a delay in the analgesic effect. No other drug interactions have been reported $\left(\right.$ Symlin $^{\circledR}$ Package Insert 2007).

\section{Phase II studies in type I diabetes}

In a 4-week double-blind trial, 215 patients with type 1 diabetes were randomized to receive either placebo; pramlintide $30 \mu \mathrm{g}$ before breakfast, lunch, dinner, and evening snack (qid); pramlintide $30 \mu \mathrm{g}$ before breakfast, lunch, and dinner (BLD); pramlintide $30 \mu \mathrm{g}$ before breakfast, dinner, evening snack (BDS); and pramlintide $60 \mu \mathrm{g}$ before breakfast and dinner.(Thompson et al 1997b) Fructosamine was decreased by $62 \mathrm{mmol} / 1(7.3 \%, \mathrm{p}=0.0026)$ in the qid, $43 \mathrm{mmol} / \mathrm{L}(15.3 \%, \mathrm{p}=0.11)$ in $\mathrm{BLD}, 47 \mathrm{mmol} / \mathrm{L}(10.5 \%$, $\mathrm{p}=0.025) \mathrm{BDS}, 46 \mathrm{mmol} / \mathrm{L}(11.6 \%, \mathrm{p}=0.062)$ in the $60 \mu \mathrm{g}$ group, and $29 \mathrm{mmol} / \mathrm{L}(11.8 \%)$ in placebo group. The daily, short-acting insulin doses were decreased by 3.6 units on average in the placebo group and reduction of 1-2.3 units in the pramlintide groups (no $\mathrm{p}$ value reported). The rate of hypoglycemia in the pramlintide group was between $12.2 \%$ and $25 \%$, and the rate in the placebo group was $26.2 \%$ (no $\mathrm{p}$ value). In the pramlintide groups, nausea occurred in $16 \%$ to $37 \%$ and anorexia $2 \%$ to $9 \%$ compared to the placebo group rates of $5 \%$ and $0 \%$ (no $\mathrm{p}$ values reported).

Nyholm et al studied the effect of adding $30 \mu \mathrm{g}$ qid of pramlintide before meals in 14 patients with type 1 diabetes in a 4-week, placebo-controlled, double-blinded, crossover trial (Nyholm et al 1999). Patients were instructed to take pramlintide 15 minutes prior to meals and evening snacks. Pramlintide therapy reduced serum fructosamine $36 \mathrm{mmol} / \mathrm{L}$ $(10.2 \%, p=0.008)$ lower than placebo therapy. Sixty-minute glucagon levels after breakfast were $36.6 \%(p=0.005)$ lower and $21.8 \%(\mathrm{p}=0.02)$ lower after lunch during pramlintide therapy versus placebo. Hypoglycemia was reported by $78.6 \%$ of patients during pramlinitide therapy and $50 \%$ 
Table I Clinical trials of pramlintide

\begin{tabular}{|c|c|c|c|c|c|c|c|c|}
\hline \multirow[t]{2}{*}{ Author (year) } & \multirow[t]{2}{*}{$\mathbf{N}$} & \multirow[t]{2}{*}{ Design } & \multirow{2}{*}{$\begin{array}{l}\text { Duration } \\
\text { (weeks) }\end{array}$} & \multirow{2}{*}{$\begin{array}{l}\text { With meal doses } \\
\text { added to insulin }\end{array}$} & \multicolumn{4}{|c|}{ Change from baseline in: } \\
\hline & & & & & $\begin{array}{l}\text { I h PPG (mmol/L) } \\
\text { vs placebo }\end{array}$ & $\begin{array}{l}2 \mathrm{~h} \text { PPG }(\mathrm{mmol} / \mathrm{L}) \\
\text { vs placebo }\end{array}$ & $A \mid C(\%)$ & Weight (kg) \\
\hline \multicolumn{9}{|l|}{ Type I studies } \\
\hline $\begin{array}{l}\text { (Nyholm et al } \\
\text { 1999) }\end{array}$ & 14 & $\mathrm{DB}, \mathrm{CO}$ & 4 & $30 \mu \mathrm{g}$ qid & $-7^{a}$ & $-4^{a}$ & & \\
\hline \multirow[t]{3}{*}{$\begin{array}{l}\text { (Weyer et al } \\
\text { 2003) }\end{array}$} & 19 & $\mathrm{R}, \mathrm{SB}, \mathrm{CO}$ & 4 & $60 \mu g$ & & & & \\
\hline & & & & + regular insulin & $-6^{a}$ & $-3.75^{\mathrm{a}}$ & & \\
\hline & & & & + lispro & $-5^{\mathrm{a}}$ & $-4.75^{a}$ & & \\
\hline $\begin{array}{l}\text { (Levetan et al } \\
\text { 2003) }\end{array}$ & 18 & & 4 & $30 \mu \mathrm{g}$ qid & $-4.4^{a}$ & $-3.6^{\mathrm{a}}$ & & \\
\hline \multirow{4}{*}{$\begin{array}{l}\text { (Fineman et al } \\
\text { 1999) }\end{array}$} & 586 & $\mathrm{DB}$ & 26 & placebo & & & +0.1 & +0.3 \\
\hline & & MC & & $60 \mu \mathrm{g}$ tid & & & $-0.2^{\mathrm{b}}$ & -1.6 \\
\hline & & & & $90 \mu \mathrm{g}$ bid & & & -0.1 & -0.7 \\
\hline & & & & $90 \mu \mathrm{g}$ tid & & & -0.1 & -1.6 \\
\hline \multirow{2}{*}{$\begin{array}{l}\text { (Whitehouse } \\
\text { et al 2002) }\end{array}$} & 480 & $\mathrm{R}, \mathrm{DB}, \mathrm{MC}$ & 52 & placebo & & & -0.16 & $+l^{a}$ \\
\hline & & & & $30-60 \mu \mathrm{g}$ qid & & & $-0.42^{\mathrm{b}}$ & $-0.5^{\mathrm{a}}$ \\
\hline \multirow{3}{*}{$\begin{array}{l}\text { (Ratner et al } \\
\text { 2004) }\end{array}$} & 538 & $\mathrm{R}, \mathrm{DB}, \mathrm{MC}$ & 52 & placebo & & & -0.04 & +0.8 \\
\hline & & & & $60 \mu \mathrm{g}$ tid & & & $-0.29^{\mathrm{b}}$ & $-0.5^{b}$ \\
\hline & & & & $60 \mu \mathrm{g}$ qid & & & $-0.34^{b}$ & $-0.5^{b}$ \\
\hline \multirow{2}{*}{$\begin{array}{l}\text { (Edelman et al } \\
\text { 2006) }\end{array}$} & 296 & $\mathrm{R}, \mathrm{DB}$ & 29 & Placebo & & & -0.5 & 1.2 \\
\hline & & & & $30-60 \mu g$ tid & & & -0.5 & -1.3 \\
\hline \multicolumn{9}{|l|}{ Type 2 studies } \\
\hline \multirow{4}{*}{$\begin{array}{l}\text { (Thompson et al } \\
\text { 1998) }\end{array}$} & 203 & $\mathrm{R}, \mathrm{DB}, \mathrm{MC}$ & 4 & placebo & & & -0.27 & -0.04 \\
\hline & & & & $30 \mu g$ qid & & & $-0.53^{b}$ & -0.36 \\
\hline & & & & $60 \mu \mathrm{g}$ tid & & & $-0.58^{\mathrm{b}}$ & $-0.89^{\mathrm{b}}$ \\
\hline & & & & $60 \mu \mathrm{g}$ qid & & & $-0.5 I^{b}$ & $-0.72^{\mathrm{b}}$ \\
\hline $\begin{array}{l}\text { (Maggs et al } \\
2004 \text { ) }\end{array}$ & 19 & $\mathrm{R}, \mathrm{SB}, \mathrm{CO}$ & $\begin{array}{l}\text { single } \\
\text { dose }\end{array}$ & $120 \mu \mathrm{g}$ & $-4.75^{a}$ & $-3.4^{a}$ & & \\
\hline \multirow[t]{4}{*}{ (Gottlieb 1999) } & 499 & $\mathrm{DB}, \mathrm{MC}$ & 26 & placebo & & & -0.1 & +0.1 \\
\hline & & & & $90 \mu \mathrm{g}$ bid & & & -0.3 & -0.8 \\
\hline & & & & $90 \mu \mathrm{g}$ tid & & & -0.4 & -1.3 \\
\hline & & & & $120 \mu g$ bid & & & $-0.4^{\mathrm{b}}$ & -1.4 \\
\hline \multirow{4}{*}{$\begin{array}{l}\text { (Ratner et al } \\
\text { 2002) }\end{array}$} & 538 & $\mathrm{R}, \mathrm{DB}, \mathrm{MC}$ & 52 & placebo & & & $-0.2^{\mathrm{a}}$ & $1.0^{\mathrm{a}}$ \\
\hline & & & & $30 \mu \mathrm{g}$ tid & & & $-0.3^{\mathrm{a}}$ & $-0.3^{\mathrm{a}}$ \\
\hline & & & & $75 \mu \mathrm{g}$ tid & & & $-0.5^{\mathrm{a}}$ & $-0.4^{\mathrm{ab}}$ \\
\hline & & & & $150 \mu \mathrm{g}$ tid & & & $-0.6^{b}$ & $-1.2^{\mathrm{ab}}$ \\
\hline
\end{tabular}


Table I (Continued)

\begin{tabular}{|c|c|c|c|c|c|c|c|c|}
\hline \multirow[t]{2}{*}{ Author (year) } & \multirow[t]{2}{*}{$\mathbf{N}$} & \multirow[t]{2}{*}{ Design } & \multirow{2}{*}{$\begin{array}{l}\text { Duration } \\
\text { (weeks) }\end{array}$} & \multirow{2}{*}{$\begin{array}{l}\text { With meal doses } \\
\text { added to insulin }\end{array}$} & \multicolumn{4}{|c|}{ Change from baseline in: } \\
\hline & & & & & $\begin{array}{l}\text { I h PPG }(\mathrm{mmol} / \mathrm{L}) \\
\text { vs placebo }\end{array}$ & $\begin{array}{l}2 \text { h PPG }(\mathrm{mmol} / \mathrm{L}) \\
\text { vs placebo }\end{array}$ & AIC (\%) & Weight (kg) \\
\hline \multirow{3}{*}{$\begin{array}{l}\text { (Hollander et al } \\
\text { 2003b) }\end{array}$} & $498^{c}$ & $\mathrm{R}, \mathrm{DB}, \mathrm{MC}$ & 52 & placebo & & & $-0.22^{\mathrm{a}}$ & $+0.5^{\mathrm{a}}$ \\
\hline & & & & $90 \mu \mathrm{g}$ bid & & & -0.35 & -0.5 \\
\hline & & & & $120 \mu \mathrm{g}$ bid & & & $-0.62^{\mathrm{b}}$ & $-1.4^{\mathrm{b}}$ \\
\hline \multirow{2}{*}{$\begin{array}{l}\text { (Riddle et al } \\
\text { 2007) }\end{array}$} & 212 & $\mathrm{DB}, \mathrm{PC}$ & 16 & placebo & & -1.9 & -0.36 & 0.7 \\
\hline & & & & $60-12 \mu \mathrm{g}$ bid-tid & & -3.1 & $-0.70^{\mathrm{a}}$ & -1.6 \\
\hline
\end{tabular}

aThese data were extrapolated from graphs as the absolute values were not listed in the text of the published study. ${ }^{\mathrm{b} p}<0.05$.

'The study initially included a $60 \mathrm{mcg}$ tid group $(\mathrm{N}=158)$, but this group was not included in the analysis so the original $\mathrm{N}=656$. Abbreviations: R, randomized; DB, double blind; MC, multi-center; PPG, postprandial glucose; SB, single blind; $C O$, crossover.

during placebo treatment. Six $(42.9 \%)$ of patients reported some gastrointestinal adverse effects during the pramlintide treatment. No $\mathrm{p}$ values were reported for the safety data. The main limitation of this trial is the small size.

The effect of adding $30 \mu \mathrm{g}$ of pramlintide tid to insulin pump therapy was studied in 18 patients with type 1 diabetes (Levetan et al 2003). Patients' 24-hour interstitial glucose levels were monitored with a continuous glucose monitoring system. At baseline, $59 \%$ of glucose measurements were over $7.77 \mathrm{mmol} / \mathrm{L}$ and $13 \%$ were less than $4.44 \mathrm{mmol} / \mathrm{L}$. During the pramlintide therapy, the number of hyperglycemic measurements decreased to $48 \%$ (no $\mathrm{p}$ values reported). The average premeal dose of insulin was decreased by $17 \%$ (no $\mathrm{p}$ value reported). The 0 to 3 hour area under the curve for glucagon and glucose was reduced by approximately $87 \%$ $(\mathrm{p}<0.05)$ and $86 \%(\mathrm{p}<0.05)$ after 4 weeks of pramlintide treatment, respectively. There was no change in fasting blood glucose $(\mathrm{p}>0.05)$. Mild to moderate nausea was the most commonly reported adverse event. The lack of a control group is a major limitation of this trial.

\section{Phase III studies in type I diabetes}

A 26-week, double-blind, placebo controlled, multi-center trial compared the effects of placebo, pramlintide $60 \mu \mathrm{g}$ tid, $90 \mu \mathrm{g}$ bid, or $90 \mu \mathrm{g}$ tid in 586 subjects with type 1 diabetes (Fineman et al 1999). Study therapy was added to premeal insulin therapy. The average age of the subjects was 38 , they had diabetes for a mean of 16 years, and their mean glycated hemogolobin (A1C) was 9.0\%. At the end of the study, the changes in A1C were as follows: $+0.1 \%$ for the placebo, $-0.2 \%$ for $60 \mu \mathrm{g}$ tid ( $\mathrm{p}=0.007),-0.1 \%$ for $90 \mu \mathrm{g}$ bid $(\mathrm{p}=0.048)$, and $-0.1 \%$ for $90 \mu \mathrm{g}$ tid $(\mathrm{p}=0.105)$.
Changes in insulin doses were not reported, which was a major limitation. There was small amount of weight gain in the placebo group and weight loss ranged between 0.7 and $1.6 \mathrm{~kg}$ in the pramlintide treated patients (Table 1). Nausea (percent not reported) was the most commonly reported side effect relative to placebo $(\mathrm{p}<0.05)$. The authors stated that nausea dissipated during the first 8 weeks of treatment, but no data documenting this was presented. Only patients receiving the $90 \mu \mathrm{g}$ bid or tid dosing had a higher rate of hypoglycemia when compared to placebo (no $\mathrm{p}$ value reported).

In a 52-week, double-blind, multicenter trial, 480 patients with type 1 diabetes were randomized to receive either premeal injections of placebo or $30 \mu \mathrm{g}$ of pramlintide 4 times per day in addition to their current insulin regimen (Whitehouse et al). If $\mathrm{A} 1 \mathrm{C}$ reductions were less than $1 \%$ at week 13, pramlintide-treated patients were re-randomized at week 20 to receive either 30 or $60 \mu \mathrm{g}$ pramlintide 4 times a day. This second randomization was done by an unblinded third party. The patients in the placebo group remained on placebo. The study population demographics were similar in each group and were as follows: over $90 \%$ Caucasian, BMI (body mass index) of $25 \mathrm{~kg} / \mathrm{m}^{2}, \mathrm{~A} 1 \mathrm{C}$ of $8.8 \%, 55 \%$ male, and average age of 40 years. Average A1C was reduced by $0.39 \%$ in the pramlintide groups and $0.12 \%$ in the placebo $(p=0.0071)$. The authors did not report the changes in A1C for the $30 \mu \mathrm{g}$ and $60 \mu \mathrm{g}$ of pramlintide groups separately. At the end of the trial the total daily insulin dose was $2.3 \%$ higher than at baseline in the pramlintide group (no $\mathrm{p}$ value for comparison to baseline was reported). The placebo group patients had a $10.3 \%(\mathrm{p}=0.017)$ increase in insulin. The treatment difference were statistically significant $(\mathrm{p}=0.0176)$. An approximate $1 \mathrm{~kg}$ weight loss was seen 
Table 2 Pramlintide dosage

\begin{tabular}{lll}
\hline Dose $(\mu \mathrm{g})$ & $\begin{array}{l}\text { Units on a U-100 } \\
\text { syringe }\end{array}$ & $\mathbf{m L}$ \\
\hline 15 & 2.5 & 0.025 \\
30 & 5 & 0.05 \\
45 & 7.5 & 0.075 \\
60 & 10 & 0.1 \\
120 & 20 & 0.2 \\
\hline
\end{tabular}

at 13 weeks in the pramlintide group compared to about a $0.25 \mathrm{~kg}$ weight gain in the placebo group ( $\mathrm{p}<0.001)$. By the end of the blinded study phase, the pramlintide group regained $0.5 \mathrm{~kg}$; making this groups final weight loss only $0.5 \mathrm{~kg}$. By the end of 52 weeks, the placebo group gained $1 \mathrm{~kg}(\mathrm{p}>0.05)$. Two-hundred thirty-six patients from all groups of this study were recruited for a 52-week, open-label, extension phase and given pramlintide $30 \mu \mathrm{g}$ qid before meals. At the end of the extension phase, the group that started on pramlintide for the first time had an approximate decrease in A1C by $0.35 \%(\mathrm{p}>0.05)$. Weight started to return to baseline values in week 65 in the subjects that received pramlintide for the entire 104 week period (Table 1). Severe hypoglycemia, defined as needing assistance of another person, intravenous glucose, or glucagon, was similar between all groups. Nausea was the most common reported adverse event and the primary reason for withdrawal, $7.4 \%$ in the pramlintide and $1.7 \%$ in the placebo groups ( $p$ valued not reported). During the second phase, the group who was switched from placebo to pramlintide had a $40.5 \%$ nausea rate and a $12.6 \%$ anorexia rate. Those who continued on pramlintide had an incidence of nausea of $14.4 \%$ and anorexia $1.6 \%$ in the second year (no $\mathrm{p}$ values were reported).

In a 52-week randomized, double-blind, placebocontrolled, multi-center study, 651 patients with type 1 diabetes were treated with either $60 \mu \mathrm{g}$ tid, $60 \mu \mathrm{g}$ qid, $90 \mu \mathrm{g}$ tid or placebo prior to meals (Ratner et al 2004). The average subject was approximately 41 years old, had a BMI of $26.5 \mathrm{~kg} / \mathrm{m}^{2}$, had diabetes for 9 years, and had a A1C of $8.9 \%$. Greater than $90 \%$ of subjects were Caucasian and 51\% were male. At 26 weeks, there was a statistically significant decline in $\mathrm{A} 1 \mathrm{C}$ in the $60 \mu \mathrm{g}$ tid and $60 \mu \mathrm{g}$ qid groups of $0.41 \%(p=0.012)$ and $0.39 \%(p=0.012)$ compared to a decrease of $0.18 \%$ in the placebo group. The investigators did not report the efficacy data of the $90 \mu \mathrm{g}$ group because this higher dose had been shown to have a higher incidence of side effects compared to the lower doses (no reference was listed). At 52 weeks, change in glycemic control in the pramlintide-treated patients was still significantly different (Table 1). The average daily insulin dose decreased by $3 \%$ to $6 \%$ in the pramlintide group, and there was no change in the placebo group ( $p$ value not reported). At 52 weeks an approximate $0.5 \mathrm{~kg}$ weight loss was seen in both pramlintide treated groups compared to 0.7 weight gain $(\mathrm{p}<0.05)$ in the placebo group. Nausea again was reported as the only adverse event. The authors state that the nausea usually diminished in the first 4 weeks of therapy but no data was reported. In the first 4 weeks of the study, a 4-fold increase in the rate of hypoglycemia was seen the pramlintide groups versus placebo ( $p$ value not reported).

The effects of adding pramlintide to either intensiveinsulin therapy or insulin-pump therapy were studied in 296 patients with type 1 diabetes in a 29-week, doubleblind, placebo-controlled, randomized, non-inferiority trial (Edelman et al 2006). Premeal pramlintide (15 $\mu \mathrm{g}$ ) was increased weekly by $15 \mu \mathrm{g}$ to a maintenance dose of $60 \mu \mathrm{g}$ during the 4-week initiation period. In both groups, insulin was adjusted during the maintenance period to achieve selfmonitored preprandial glucose levels of 6.1 to $7.7 \mathrm{mmol} / \mathrm{L}$ and self-monitored postprandial glucose levels of 7.7 to $9.9 \mathrm{mmol} / \mathrm{L}$. Hypoglycemia was the primary endpoint and the secondary endpoint was change in postprandial glucose, $\mathrm{A} 1 \mathrm{C}$, insulin doses, and weight. The baseline average A1C was $8.1 \%$, average BMI was $27.8 \mathrm{~kg} / \mathrm{m}^{2}$, the average duration of diabetes was 19 to 21 years, $40.8 \%$ to $48.6 \%$ of patients were male, and the average age was 41 years. The baseline average total insulin dose in patients on multiple injections per day was $66.5 \pm 32.6$ units and $47.3 \pm 20.2$ units in patients on an insulin pump. The final total daily insulin doses were $12 \%$ lower in the pramlintide-treated subjects compared to $1 \%$ higher in the placebo-treated patients. Approximately, $1 \%$ of pramlintide treated subjects were on the $15 \mu \mathrm{g}$ dose, $21 \%$ were on the $30 \mu \mathrm{g}$ dose, $1 \%$ were on the $45 \mu \mathrm{g}$ dose, and $78 \%$ were on the $60 \mu \mathrm{g}$ dose. The A1C mean change in the pramlintide and insulin groups was $0.5 \%(\mathrm{p}<0.001$ versus baseline). There was no $\mathrm{p}$ value reported for the comparison of the changes in A1Cs in the pramlintide group versus the placebo group. In patients treated with pramlintide, postprandial glucose values were below target $68 \%, 71 \%$, and $70 \%$ of the time after breakfast, lunch, and dinner, respectively. And in the placebo-treated patients, the percentage of time that breakfast, lunch, and dinner postprandial glucoses were below target was $51 \%, 61 \%$, and $58 \%$, respectively $(\mathrm{p}<0.0001)$. Weight was reduced by pramlintide therapy $(1.3 \pm 0.3 \mathrm{~kg})$ and increased with placebo therapy 
$(1.2 \pm 0.24 \mathrm{~kg}, \mathrm{p}<0.0001)$. Adverse events that occurred more frequently were reduced appetite, vomiting and nausea. Suppressed appetite occurred in $8.8 \%$ of pramlintide-treated patients and $2 \%$ in the placebo-treated group $(\mathrm{p}<0.05)$. Vomiting occurred in $13.5 \%$ and $6.1 \%$ of the pramlintide and placebo groups $(\mathrm{p}<0.05)$. Nausea was reported by $62.8 \%$ of pramlintide-treated subjects and $36.1 \%$ of placebo-treated patients $(\mathrm{p}<0.01)$. The pramlintide event rate per patient-year of severe hypoglycemia was between 0.54 and 0.75 compared to 0.28 and 0.42 in the placebo group ( $p<0.05)$. Marreoro et al (2007) assessed satisfaction of pramlintide therapy in 266 patients from the Edelman study (Edelman et al 2006; Marrero et al 2007). On all but two patient-reported outcomes, patients treated with pramlintide reported improved satisfaction $(p<0.05)$ with their diabetes treatment.

\section{Phase II studies in type 2 diabetes}

The first published trial of subjects with type 2 diabetes was single-blind, randomized, cross-over trial $(\mathrm{N}=24)$ (Thompson et al 1997a). Ten patients were treated with insulin only, 2 patients received insulin and oral agents, 7 patients were on oral agents, and 5 patients were managed with diet alone. Subjects were given a $100 \mu \mathrm{g} / \mathrm{h}$ pramlintide infusion for 5 hours. And at the beginning of the first hour the patients ingested $7 \mathrm{kcal} / \mathrm{kg}$ of Sustacal ${ }^{\circledR}$. The mean insulin levels were $43 \%$ lower during pramlintide infusion when compared to placebo infusion $(\mathrm{p}=0.00025)$. More patients reported nausea (58\%) while receiving pramlintide compared to patients on placebo ( $25 \%$, no $\mathrm{p}$ values reported).

The effect of adding premeal pramlintide $30 \mu \mathrm{g}$ qid, $60 \mu \mathrm{g}$ tid and $60 \mu \mathrm{g}$ qid to insulin therapy was studied in 203 subjects with type 2 diabetes (Thompson et al 1998). This was a randomized, double-blind, placebo-controlled, multicenter, 4-week trial. By the end of the trial, fructosamine was decreased by $17.5 \mathrm{mmol} / \mathrm{L}(5.8 \%)$ in the $30 \mu \mathrm{g}$ group $(\mathrm{p}=0.029), 24.1 \mathrm{mmol} / \mathrm{L}(8.0 \%)$ in $60 \mu \mathrm{g}$ tid group $(\mathrm{p}=0.003), 22.6 \mathrm{mmol} / \mathrm{L}(7.6 \%)$ in $60 \mu \mathrm{g}$ qid group $(\mathrm{p}=0.001)$, and $3.5 \mathrm{mmol} / \mathrm{L}(1.1 \%)$ in the placebo group. Changes in weight and $\mathrm{A} 1 \mathrm{C}$ are listed in Table 1. The change in weight was not statistically significant. Nausea was reported by $10 \%$ to $14 \%$ of pramlintide-treated subjects. The rate of hypoglycemia was similar in all groups, but no incidence or $\mathrm{p}$ value was reported.

A single-blind, placebo-controlled trial examined the effects of varying the time between administration of pramlintide $120 \mu \mathrm{g}$ and initiation of the meal (Maggs et al 2004). Patients $(\mathrm{N}=19)$ had type 2 diabetes and were treated with lispro at time 0 relative to the meal. Subjects received subcutaneous placebo or pramalintide at $-15,0,+15$, or +30 minutes relative to a standardized meal. Relative to placebo glucose 0 to 4 hour area under the curve was reduced by $42 \%(p=0.05), 81 \%(p<0.05), 73 \%(p<0.05)$ and $59 \%(\mathrm{p}<0.05)$ when pramlintide is given at $-15,0,+15$, or +30 minutes, respectively. Percent reduction and $p$ values are for comparison to placebo. Hypoglycemia was the only reported adverse event (the percent incidence and $\mathrm{p}$ value were not reported).

\section{Phase III studies in type $\mathbf{2}$ diabetes}

The earliest large-scale, long-term trial in patients with type 2 diabetes examined the effect of pramlinitide in a 26-week, multi-center, double-blind, placebo-controlled study ( $\mathrm{N}=499)$ (Gottlieb 1999). The mean baseline A1C was $9.4 \%$, the average age was 58 years, and the mean duration of diabetes was 13.5 years. Either $90 \mu \mathrm{g}$ bid, $90 \mu \mathrm{g}$ tid, $120 \mu \mathrm{g}$ bid of premeal pramlintide, or placebo was added to insulin therapy. At 26 weeks, the A1C decreased by $0.1 \%$, $0.3 \%(\mathrm{p}=0.068), 0.4 \%(\mathrm{p}=0.079)$, and $0.4 \%(\mathrm{p}=0.048)$ in the placebo, $90 \mu \mathrm{g}$ bid, $90 \mu \mathrm{g}$ tid, and $120 \mu \mathrm{g}$ bid groups, respectively. The total daily insulin dose increased in the placebo group and decreased in the pramlintide treated patients $(\mathrm{p}=0.0002)$; the authors did not report the percent changes of insulin doses. At the end of the trial period, weight had also changed by $+0.1 \pm 0.3 \mathrm{~kg},-0.8 \pm 0.3 \mathrm{~kg},-1.3 \pm$ $0.3 \mathrm{~kg},-1.4 \pm 0.3 \mathrm{~kg}$ in the placebo, $90 \mu \mathrm{g}$ bid, $90 \mu \mathrm{g}$ tid, and $120 \mu \mathrm{g}$ bid groups, respectively. Nausea was the only reported side effect. The rate of hypoglycemia was equivalent in all groups. No statistical analyses of the comparisons to baselines values were reported.

In a 52-week trial, Ratner et al (2002) studied the effects of pramlintide in patients with type 2 diabetes who were on insulin. In this multi-center, double-blind trial, patients were randomized to placebo, $30 \mu \mathrm{g}, 75 \mu \mathrm{g}$ or $150 \mu \mathrm{g}$ of pramlintide tid. In addition to insulin, up to $8 \%$ of each group was treated with sulfonylureas and up to $18.9 \%$ received metformin as a part of their baseline regimen. There were no statistical differences in baseline demographics or treatment of diabetes. The subjects' average age ranged from 55.5 to 57.5 years, $56 \%$ to $62 \%$ of each group was male, each group was between $76 \%$ and $81 \%$ Caucasian, the BMI ranged from 30.4 to $31.1 \mathrm{~kg} / \mathrm{m}^{2}$ and the baseline $\mathrm{A} 1 \mathrm{C}$ ranged from $9.0 \%$ to $9.3 \%$. According to values extracted from a graph, there was a $0.2 \%$ (p > 0.05), 0.3\% (p > 0.05), 0.5\% (p > 0.05), 0.6\% $(\mathrm{p}<0.05)$ decrease in $\mathrm{A} 1 \mathrm{C}$ in the placebo, $30 \mu \mathrm{g}, 75 \mu \mathrm{g}$, and $150 \mu \mathrm{g}$ groups, respectively. The changes for the placebo, 
$30 \mu \mathrm{g}$, and $75 \mu \mathrm{g}$ groups were extracted from a figure because the results were not reported in the text of the article. Insulin doses were increased by $15.4 \%$ in the placebo group and by $7.9 \%$ to $10.9 \%$ in the pramlintide groups (statistical significance not reported). Similar to other studies a weight loss was observed in the pramlinitide-treated subjects (Table 1). Nausea occurred in $16.9 \%$ of the placebo group compared to $14.8 \%$ in the $30 \mu \mathrm{g}$ group, $26.5 \%$ in the $75 \mu \mathrm{g}$ group, and $22.9 \%$ in the $150 \mu \mathrm{g}$ group (p values were not reported). Similar with other studies, the authors reported transient nausea but did not present any evidence to support this statement. All groups had a similar incidence of hypoglycemia, but no incidence or statistical results were reported.

In another 52-week, double-blind, multi-center trial patients with type 2 diabetes $(\mathrm{N}=656)$ were randomized to receive placebo, $60 \mu \mathrm{g}$ tid, $90 \mu \mathrm{g}$ bid or $120 \mu \mathrm{g}$ bid of pramlintide prior to meals (Hollander et al 2003b). In addition to insulin, patients were also treated with metformin (14\%), sulfonylureas $(10 \%)$, or the combination of sulfonylureas and metformin (2\%). The investigators decided not to report the findings from the $60 \mu \mathrm{g}$ tid group because, while this study was ongoing, information from another study, which was not referenced, became available that indicated $60 \mu \mathrm{g}$ bid was not effective. The results of the other groups are presented in Table 1. Insulin and oral hypoglycemic therapy remained stable throughout the trial in all groups. Nausea was the most common side effect; the percent incidence and $p$ value were not reported. During the first 4 weeks of therapy, there were three times more hypoglycemic episodes in the $120 \mu \mathrm{g}$ group compared to placebo $(\mathrm{p}<0.05)$.

Riddle et al (2007) investigated the efficacy and safety of the addition of pramlintide ( 60 or $120 \mu \mathrm{g} \mathrm{bid/tid)} \mathrm{to} \mathrm{patients}$ with an uncontrolled A1C on insulin glargine (with or without oral anti-diabetes medications) in a 16-week, double-blind, placebo-controlled trial involving 212 patients with type 2 diabetes. Patients were on average 55 years of age. Baseline BMI was $35 \mathrm{~kg} / \mathrm{m}^{2}$ and $\mathrm{HbAlc}$ was $8.5 \%$. Patients were titrated to the $120 \mu \mathrm{g}$ dose of pramlintide 3 to 7 days after initiation if no clinically significant nausea occurred. Ninetythree percent of patients were titrated to the $120 \mu \mathrm{g}$ dose. Once the maintenance dose was achieved, investigators were instructed to titrate insulin glargine doses to achieve fasting glucose concentrations of $\geq 3.9 \mathrm{mmol} / \mathrm{L}$ to $<5.6 \mathrm{mmol} / \mathrm{L}$. Two co-primary endpoints were evaluated. The first was change in A1C from baseline to week 16. The second co-primary composite endpoint assessing the percentage of patients meeting all of the following criteria: 1) A1C $\leq 7 \%$ or an $\mathrm{A} 1 \mathrm{C}$ reduction $\geq 0.5 \% 2$ ) average daily postprandial glucose increments $\leq 40 \mathrm{mg} / \mathrm{dL} 3$ ) no weight gain 4) and no severe hypoglycemia (requiring assistance). A1C values in the pramlintide-treated patients were significantly reduced from baseline versus placebo-treated patients $(-0.7 \pm 0.11 \%$ versus $-0.36 \pm 0.08 \%, \mathrm{p}<0.05)$. The mean A1C values at week 16 for pramlintide and placebo were $7.8 \%$ and $8.1 \%$, respectively. Significantly more pramlintide-treated patients achieved the composite endpoint versus placebo (25 versus $7 \%$; $<<0.001$ ). Weight loss was seen with pramlintide and weight gain was seen with placebo $(-1.6 \pm$ $0.3 \mathrm{~kg}$ versus $+0.7 \pm 0.3 \mathrm{~kg} ; \mathrm{p}<0.0001)$. Nausea occurred in $31 \%$ of pramlintide and $10 \%$ of placebo treated patients. Hypoglycemia occurred in $44 \%$ of pramlintide and $47 \%$ of placebo treated patients (no $\mathrm{p}$ value reported). No treatment related severe hypoglycemia occurred in either group.

Rubin et al assessed the treatment satisfaction of patients treated with pramlintide and insulin therapy in an open-label study that included 240 patients with type 1 diabetes and 160 patients with type 2 diabetes (Rubin and Peyrot 2007). Seven-point glucose profiles and weight were assessed at baseline, 1 month, 3 months, and 6 months. A1C was assessed at baseline, 3, and 6 months. At week 1, 3, and 6 months, patients completed a 14 -item treatment satisfaction questionnaire (TSQ). The TSQ assessed how the patients felt the study medication affected control of glucose, appetite, weight, adherence, number of injections, well-being, and willingness to continue pramlintide in the future. The questions were clustered into 3 sets of categories - glucose control, eating/weight control, and general benefits. All items were scored (maximum score of 2 and minimum score of -2 ). A score of 0 indicates no advantage of pramlintide over the patient's previous diabetes regimen. Positive scores indicate an advantage of pramlintide and negative scores indicate a disadvantage of pramlintide. Patients rated the pramlintide treatment regimen significantly better than their previous treatment in all 3 sets of items - glucose control, eating/ weight control, and general benefits at 1, 3, and 6 months. Treatment satisfaction was higher for those who experienced better clinical outcomes (decreases in insulin, weight, and postprandial glucose levels). The majority of patients (96\%) said they would like to continue using pramlintide.

Elkind-Hirsch et al reported the real world, clinical experiences when pramlintide was added to the treatment regimens of insulin-requiring patients with type 2 diabetes (Elkind-Hirsch et al 2008). The population consisted of 54 women and $38 \mathrm{men}$ in the age range of 24 to 80 years. The majority of patients were overweight or obese. Retrospective analysis of data showed that 24 weeks of pramlintide 
therapy in addition to insulin (with or without other oral anti-diabetic medications) resulted in a significant decrease in $\mathrm{A} 1 \mathrm{C}(8.32 \pm 0.17$ to $7.86 \pm 0.16 \% ; \mathrm{p}=0.0125)$. Therapy with pramlintide also resulted in a significant decrease in body weight $(104.4 \pm 2.1$ to $103.2 \pm 2.07 \mathrm{~kg} ; \mathrm{p}=0.029)$ and BMI $\left(35.2 \pm 0.6\right.$ to $\left.34.7 \pm 0.6 \mathrm{~kg} / \mathrm{m}^{2} ; \mathrm{p}=0.019\right)$. There were no significant differences between baseline and follow-up on abdominal girth, total cholesterol (TC), triglycerides (TG) or high-density lipoprotein cholesterol (HDL-C). Low-density lipoprotein cholesterol (LDL-C) was reduced by $0.19 \mathrm{mmol} / \mathrm{L}$ $(p=0.029)$. This change, according to the authors, could not be attributed to changes in lipid lowering medications.

\section{Post-hoc analysis}

A post-hoc analysis of Ratner et al (2002) and Hollander et al (2003b) examined changes in A1C and weight in African American, Hispanic, and Caucasian patients treated with either placebo or pramlinitide $120 \mu \mathrm{g}$ bid or $15 \mu \mathrm{g}$ tid (Maggs et al 2003). After 52 weeks of therapy, there was a $0.7 \%$, $0.3 \%$ and $0.5 \%$ reduction in $\mathrm{A} 1 \mathrm{C}$ in African-Americans, Hispanics and Caucasians, respectively. African-Americans lost $4.1 \mathrm{~kg}$, Caucasians lost $2.4 \mathrm{~kg}$, and Hispanic lost $2.3 \mathrm{~kg}$. There were no $\mathrm{p}$ values reported for any of these comparisons, which is a limitation of this trial.

In a post-hoc analysis of the data from the same patients in the Riddle et al (2007) trial, Wysham et al (2008) described the effects of pramlintide as an adjunct to basal insulin on markers of cardiovascular risk including: weight, high sensitivity C-reactive protein (hs-CRP), TGs, HDL-C, LDL-C, and blood pressure. At baseline, the average hs-CRP concentrations were $>3 \mathrm{mg} / \mathrm{L}$ and mean TGs were $176 \mathrm{mg} / \mathrm{dL}$. Baseline LDL-C was $94 \mathrm{mg} / \mathrm{dL}$ and $104 \mathrm{mg} / \mathrm{dL}$ and baseline HDL-C was $49 \mathrm{mg} / \mathrm{dL}$ and $48 \mathrm{mg} / \mathrm{dl}$ in the placebo and pramlintide groups, respectively. Baseline blood pressure was $129 / 79 \mathrm{mmHg}$ and $130 / 79 \mathrm{mmHg}$ in the placebo and pramlinitide groups, respectively. Slightly more patients were taking metformin in the placebo group versus the pramlintide group (75 versus 67); whereas, slightly more patients were taking thiazolidinediones in the pramlintide group versus the placebo group (32 versus 20). At week 16, hs-CRP was reduced significantly more in the pramlintide group than in the placebo group $(-0.8 \pm 0.2 \mathrm{mg} / \mathrm{dL}$ versus $0.1 \pm 0.2 \mathrm{mg} / \mathrm{dL} ; \mathrm{p}<0.01)$. There were favorable trends in TG reduction with pramlintide versus placebo especially in those with TGs $>150 \mathrm{mg} / \mathrm{dL}$ and $>200 \mathrm{mg} / \mathrm{dL}$ at baseline. However, these changes were not statistically significant versus placebo. As reported previously, there were significant reductions in body weight in the pramlintide group versus the placebo group. There were no statistically significant changes versus placebo on LDL-C or HDL-C. Although systolic and diastolic blood pressures were reduced more in the pramlintide treated patients versus placebo treated patients, there was no statistical significance between the two groups. The authors concluded that pramlintide as an adjunct to basal insulin was associated with improvements in several cardiovascular risk markers (hs-CRP, body weight, and TGs) and that long term trials are warranted to determine the drug's potential effects on cardiovascular risk

A post-hoc analysis the Gottlieb (Gottlieb 1999) and Hollander et al ( 2003b) trials examined the effects of pramlintide therapy in a subpopulation of patients with A1C of $7.5 \%$ to $8 \%$ (Hollander et al 2003a). Insulin doses were not changed in the 166 patients treated with either placebo or pramlintide $120 \mu \mathrm{g}$ bid. The final A1C was $0.1 \%$ higher in the placebo group but $0.43 \%$ lower in the pramlintide treated group $(\mathrm{p}<0.05)$.

\section{Safety and tolerability}

None of the long term studies reported evidence of hepatic, renal, cardiovascular, or pulmonary toxicity associated with pramlintide therapy (Fineman et al 1999; Gottlieb 1999; Whitehouse et al 2002; Hollander et al 2003b; Ratner et al 2002, 2004). All of these studies reported nausea as the main side effect. Most of the studies reported the nausea as transient, lasting between 2 and 8 weeks (Fineman et al 1999; Whitehouse et al 2002; Gottlieb 1999; Ratner et al 2002, 2004). However, none of the studies reported data to document the reduction of nausea. The rate of nausea varied between 10\% and 59\% (Thompson et al 1998; Whitehouse et al 2002; Hollander et al 2003b, Ratner et al 2002, 2004). and the percentage of patients reported to have dropped out of the study because of nausea was between $5.4 \%$ and $62.8 \%$ (Whitehouse et al 2002; Ratner et al 2002, 2004; Edelman et al 2006). The use of larger doses was associated with a higher incidence of nausea (Hollander et al 2003b; Ratner et al 2002, 2004; Edelman et al 2006, Riddle et al 2007). Hollander et al (2003b) found the increased nausea was not associated with more weight loss and that the incidence of nausea was not increased by the concomitant use of metformin.

As blood glucose approaches euglycemia, the risk for hypoglycemia increases (United Kingdom Prospective Diabetes Study Group 1998a, b; Boyle et al 2001). In all of the long term trials, the rate of hypoglycemia was similar in the pramlintide groups compared to the placebo groups 
(Gottlieb 1999; Ratner et al 2002; Whitehouse et al 2002; Edelman et al 2006; Riddle et al 2007). In one 52-week study, hypoglycemia was 4 times more likely in the first 4 weeks of pramlintide therapy compared to placebo, but after the first 4 weeks the risk was equal (Ratner et al 2004; Edelman et al 2006). Hollander et al (2003b) found a greater risk of hypoglycemia during treatment with pramlintide $120 \mu \mathrm{g}$ bid compared to the $60 \mu \mathrm{g}$ bid, $90 \mu \mathrm{g}$ bid, and placebo groups. This difference was only seen during the first 4 weeks of this 52 week study. Another study also found that the $90 \mu \mathrm{g}$ bid and tid groups had a higher rate of hypoglycemia than the groups treated with placebo or $60 \mu \mathrm{g}$ tid (Fineman et al 1999). To minimize the risk of hypoglycemia, manufacture recommends reducing the dose of short-acting premeal insulin by $50 \%$ when initiating pramlintide (Symlin ${ }^{\circledR}$ Package Insert 2007). To date the agent has not been reported to cause pancreatitis.

\section{Contraindications}

Pramlintide slows gastric emptying, therefore, is not recommended in patients with gastroparesis. In addition, history of frequent hypoglycemia is a relative contraindication to pramlintide because it will increase the risk of low blood glucose. Therapy with this agent is not advisable in patients that are not compliant with current therapy or those that are not willing to monitor blood glucose frequently (Symlin ${ }^{\circledR}$ Package Insert 2007).

\section{Discussion}

The benefits of pramlintide are reduction of A1C, postprandial glucose, a potential reduction of total daily insulin dose, and possible weight loss. The studies indicate that pramlintide reduces $\mathrm{A} 1 \mathrm{C}$ between $0.2 \%$ and $0.4 \%$ in patients with type 1 diabetes and $0.4 \%$ and $0.6 \%$ in patients with type 2 diabetes with an initial A1C of $8 \%$ to $9 \%$ (Fineman et al 1999; Gottlieb 1999; Whitehouse et al 2002; Ratner et al 2002, 2004; Edelman et al 2006; Riddle et al 2007). Additional study of the use of pramlintide therapy in patients with A1C over $9.0 \%$ is needed. Pramlintide typically reduces 2 -hour postprandial glucose between 4 and $6 \mathrm{mmol} / \mathrm{L}$ and has a minimal affect on fasting glucose. The 0.5 to $1 \mathrm{~kg}$ weight loss observed with pramlintide therapy may be beneficial compared to the increase in weight which is commonly seen with insulin, sulfonylureas and thiazolidinediones (Fineman et al 1999; Gottlieb 1999; Ratner et al 2002, 2004; Whitehouse et al 2002; Hollander et al 2003b). However, findings after 104 weeks of therapy suggest that the weight loss may be transient (Whitehouse et al 2002). One investigator ruled out the possibility that nausea may be the reason for weight loss (Hollander et al 2003b). Randomized controlled trials longer than one year are necessary to establish the long-term weight loss potential of pramlintide.

The major limitations to pramlintide therapy include hypoglycemia, nausea, subcutaneous route of administration, and the use and expense of another medication. The rate of hypoglycemia in the pramlintide group was 2 to 4 times greater than placebo group's rate in the first 4 weeks of therapy (Ratner et al 2002; Hollander et al 2003b) The manufacturer recommends reducing the dose of premeal insulin by $50 \%$ when starting pramlintide. No dose adjustment baseline therapy with sulfonylurea or metformin is recommended. However, close monitoring of blood glucose levels is imperative whenever pramlintide therapy is started. Nausea was the most frequently reported side effect and the most common reason for subject withdrawal. Most investigators stated that nausea dissipated after 4 weeks of therapy, but no data were reported to support these statements.

Pramlintide is indicated for use with mealtime insulin and combining both agents in the same syringe for simultaneous administration would reduce the number of injections necessary. However, the package insert states pramlintide should not be mixed in the same syringe with insulin (Symlin ${ }^{\circledR}$ Package Insert 2007). However, one study that showed that mixing pramlintide and isophane or regular insulin into the same syringe does not change the pharmacokinetics or pharmacodynamics of either agent (Weyer et al 2005). Additional studies to determine the compatibility of mixing pramlintide and a variety of insulin products are warranted.

To our knowledge, there are no pharmacoeconomic studies of pramlintide therapy. The average wholesale price of a $0.6 \mathrm{mg} / \mathrm{mL} 5 \mathrm{ml}$ vial is US\$127 (Rice 2008) It would cost about US\$127 to \$254 per month for a patient who uses 30 to $60 \mu \mathrm{g}$ tid. Studies must be done to determine cost benefit.

\section{Conclusion}

Pramlintide is an amylin analog that can be used with mealtime insulin in the treatment of type 1 and type 2 diabetes. In patients with type 2 diabetes, pramlintide can also be added to sulfonylurea monotherapy, metformin monotherapy, the combination of a sulfonlyurea and metformin, or the combination of sulfonylurea, metformin and insulin. Therapy with pramlintide reduces $\mathrm{A} 1 \mathrm{C}$ by $0.2 \%$ to $0.6 \%$ and the 2-hour postprandial glucose by 3.4 to $5 \mathrm{mmol} / \mathrm{L}$. In the 1 -year studies, pramlintide therapy decreased weight modestly, but in one 52-week, open-label, extension trial weight returned to baseline levels. There is an ongoing trial that examines 
the effectiveness of pramlintide as a weight loss agent (www.ClinicalTrials.gov, 2008). Pramlinitide has a favorable safety profile and minimal contraindications. Transient nausea is the most common adverse event. To reduce the risk of hypoglycemia, a reduction of premeal insulin by $50 \%$ and close glucose monitoring is warranted.

\section{Disclosures}

$\mathrm{TAB}$ is an employee of AstraZeneca. The other authors have no conflicts of interest to disclose.

\section{References}

American Diabetes Association. 2008. Economic costs of diabetes in the US in 2007. Diabetes Care, 31:596-615.

American Diabetes Association. 2005. Diagnosis and classification of diabetes mellitus. Diabetes Care, 27:S37.

Beaumont K, Kenney MA, Young AA, et al. 1993. High affinity amylin binding sites in rat brain. Mol pharmacol, 44:493-7.

Boyle J, Honeycutt A, Narayan K, et al. 2001. Projection of diabets burdent through 2050; the impact of changing demography and disease prevalence in the US Diabetes Care, 24:936-1940.

Centers for Disease Control and Prevention. 2005. National diabetes fact sheet: general information and national estimates on diabetes in the United States, 2005. Atlanta, GA: US Department of Health and Human Services, Centers for Disease Control and Prevention.

Cooper GJ, Willis AC, Clark A, et al. 1987. Purification and characterization of a peptide from amyloid-rich pancreases of type 2 diabetic patients. Proc Natl Acad Sci U S A, 84:628-32.

Diabetes Control and Complications Research Trial Group. 1993.The effect of intensive treatment of diabets on development and progression of long-term complication in insulin dependent diabetes mellitus. $N$ Engl J Med, 329:77-986.

Edelman S, Garg S, Frias J, et al. 2006. A double-blind, placebo-controlled trial assessing pramlintide treatment in the setting of intensive insulin therapy in type 1 diabetes. Diabetes Care, 29:189-95.

Elkind-Hirsch K, Butler WJ, Bhushan M, et al. 2008.Clinical experience with the addition of pramlintide in patients with insulin-requiring type 2 diabetes. Diabetes Care, 31:39-40.

Fineman M, Gottlieb A, Bahner A, et al. 1999. Pramlintide therapy in addition to insulin in type 1 diabetes: effect on metabolic control after 6 months. Diabetologia, 42:A232.

Fineman M, Weyer C, Maggs D G, et al. 2002a. The human amylin analog, pramlintide, reduces postprandial hyperglucagonemia in patients with type 2 diabetes mellitus. Horm Metab Res, 34:504-8.

Fineman MS, Koda JE, Shen LZ, et al. 2002b. The human amylin analog, pramlintide, corrects postprandial hyperglucagonemia in patients with type 1 diabetes. Metabolism, 51:636-41.

Gottlieb A. 1999. Pramlintide therapy in addition to insulin in type 2 diabetes: effect on metabolic control after 6 monhts. Diabetologia, 42:A232.

Grabauska G, Zhou S, Das S, et al. 2004. Prolactin-releasing peptide affects gastric motor function in rat by modulating synaptic transmssion in the dorsal vagal complex. $J$ Physiol, 561:821-39.

Hoerger TJ, Segel JE, Gregg EW, et al. 2008. Is glycemic control improving in US adults? Diabetes Care, 31:81-6.

Hollander P, Ratner R, Fineman M, et al. 2003a. Addition of pramlintide to insulin therapy lowers $\mathrm{HbAlc}$ in conjunction with weight loss in patients with type 2 diabetes approaching glycaemic targets. Diabetes Obes Metab, 5:408-14.

Hollander PA, Levy P, Fineman MS, et al. 2003b. Pramlintide as an adjunct to insulin therapy improves long-term glycemic and weight control in patients with type 2 diabetes: a 1-year randomized controlled trial. Diabetes Care, 26:784-90.
Kellmeyer TA, Kesty NC, Wang Y, et al. 2007. Pharmacokinetics of an oral drug (acetaminophen) administered at various times relative to subcutaneous injection of pramlintide in subjects with type 2 diabetes. $J$ Clin Pharmacol, 47:798-805.

Koda JE, Fineman M, Rink TJ, et al. 1992. Amylin concentrations and glucose control. Lancet, 339:1179-80.

Kong MF, King P, MacDonald IA, et al. 1997. Infusion of pramlintide, a human amylin analogue, delays gastric emptying in men with IDDM. Diabetologia, 40:82-8.

Kong MF, Stubbs TA, King P, et al. 1998. The effect of single doses of pramlintide on gastric emptying of two meals in men with IDDM. Diabetologia, 41:577-83.

Levetan C, Want LL, Weyer C, et al. 2003. Impact of pramlintide on glucose fluctuations and postprandial glucose, glucagon, and triglyceride excursions among patients with type 1 diabetes intensively treated with insulin pumps. Diabetes Care, 26:1-8.

Lutz T, Mollet A, Rushing P, et al. 2001. The anorectic effect of a chronic peripheral infusion of amylin is abolished in area postrema/nucleus of solitary tract (AP/NTS) lesioned rats. Int J Obes Relat Metab Disord, 25:1005-11.

Maggs D, Shen L, Strobel S, et al. 2003. Effect of pramlintide on A1C and body weight in insulin-treated African Americans and Hispanics with type 2 diabetes: a pooled post hoc analysis. Metabolism, 52:1638-42.

Maggs DG, Fineman M, Kornstein J, et al. 2004. Pramlintide reduces postprandial glucose excursions when added to insulin lispro in subjects with type 2 diabetes: a dose-timing study. Diabetes Metab Res Rev, 20:55-60.

Marrero DG, Crean J, Zhang B, et al. 2007. Effect of adjunctive pramlintide treatment on treatment satisfaction in patients with type 1 diabetes. Diabetes Care, 30:210-6.

Martinez A, Kapas S, Miller MJ, et al. 2000. Coexpression of receptors for adrenomedullin, calcitonin gene-related peptide, and amylin in pancreatic beta-cells. Endocrinology, 141:406-11.

National Institute of Diabetes and Digestive and Kidney Disease. 2008. National Diabetes Statistics, 2007 fact sheet. Bethesda, MD: US Department of Health and Human Services, National Institutes of Health, 2008.

Nyholm B, Orskov L, Hove KY, et al. 1999. The amylin analog pramlintide improves glycemic control and reduces postprandial glucagon concentrations in patients with type 1 diabetes mellitus. Metabolism, 48:935-41.

Pittner R, Albrandt K, Beaumont K. 1994. Molecular physiology of amylin. $J$ Cell Biochem, 555:19-28.

Ratner RE, Dickey R, Fineman M, et al. 2004. Amylin replacement with pramlintide as an adjunct to insulin therapy improves long-term glycaemic and weight control in Type 1 diabetes mellitus: a 1-year, randomized controlled trial. Diabetic Medicine, 21:1204-12.

Ratner RE, Want LL, Fineman MS, et al. 2002. Adjunctive therapy with the amylin analogue pramlintide leads to a combined improvement in glycemic and weight control in insulin-treated subjects with type 2 diabetes. Diabetes Technol Ther, 4:51-61.

Rice T. (Ed) 2008. Redbook Pharmacy's Fundamental Reference: August 2008 Update. Montvale, NJ: Thomas Reuters.

Riddle, M., Frias, J., Zhang, B., et al. 2007. Pramlintide improved glycemic control and reduced weight in patients with type 2 diabetes using basal insulin. Diabetes Care, 30, 2794-9.

Rubin RR, Peyrot M. 2007. Assessing treatment satisfaction in patients treated with pramlintide as an adjunct to insulin therapy. Curr Med Res Opin, 23, 1919-29.

Sexton PM, Paxinos G, Kenney MA, et al. 1994. In vitro autoradiographic localization of amylin binding sites in rat brain. Neuroscience, 62:553-67.

Symlin ${ }^{\circledR}$ Package Insert. 2007. Symlin [package insert]. December.

Thompson RG, Gottlieb A, Organ K, et al. 1997a. Pramlintide: a human amylin analogue reduced postprandial plasma glucose, insulin, and C-peptide concentrations in patients with type 2 diabetes. Diabet Med, 14:547-55. 
Thompson RG, Pearson L, Kolterman OG. 1997b. Effects of 4 weeks' administration of pramlintide, a human amylin analogue, on glycaemia control in patients with IDDM: effects on plasma glucose profiles and serum fructosamine concentrations. Diabetologia, 40:1278-85.

Thompson RG, Pearson L, Schoenfeld SL, et al. 1998. Pramlintide, a synthetic analog of human amylin, improves the metabolic profile of patients with type 2 diabetes using insulin. The Pramlintide in Type 2 Diabetes Group. Diabetes Care, 21:987-93.

Thompson RG, Peterson J, Gottlieb A, et al. 1997c. Effects of pramlintide, an analog of human amylin, on plasma glucose profiles in patients with IDDM: results of a multicenter trial. Diabetes, 46:632-6.

United Kingdom Proscpective Diabetes Study Group. 1998a. Effect of intensive blood glucose control with metformin on complications in overweight patients with type 2 (UKPDS 34). Lancet, 352:854-65.

United Kingdom Proscpective Diabetes Study Group. 1998b. Intensive blood glucose control with sulphonylureas or insulin compared with conventional treatment and risk of complications in patients with type 2 diabetes (UKPDS 33). Lancet, 352:837-53.

Weyer C, Fineman M, Strobel S, et al. 2005. Properties of pramlintide and insulin upon mixing. Am J Health-Syst Pharm, 62:816-22.
Weyer C, Gottlieb A, Kim DD, et al. 2003. Pramlintide reduces postprandial glucose excursions when added to regular insulin or insulin lispro in subjects with type 1 diabetes: a dose-timing study. Diabetes Care, 26:3074-9.

Weyer C, Maggs DG, Young AA, et al. 2001. Amylin replacement with pramlintide as an adjunct to insulin therapy in type 1 and type 2 diabetes mellitus: a physiological approach toward improved metabolic control.[erratum appears in Curr Pharm Des 2001 Dec; 7(18):1967]. Curr Pharm Des, 7:1353-73.

Whitehouse, F., Kruger, D. F., Fineman, M., et al. 2002) A randomized study and open-label extension evaluating the long-term efficacy of pramlintide as an adjunct to insulin therapy in type 1 diabetes.[see comment]. Diabetes Care, 25:724-30.

www.clinicaltrials.gov. 2008. A study to examine the long term effect of pramlintide on body weight and its safety and tolerability in obese subjects [online]. Accessed August 18, 2008. URL: http://clinicaltrials. gov/ct2/show/NCT00189514?term=pramlintide\&rank=3

Wysham, C, Lush, C, Zhang, B., et al. 2008) Effect of pramlintide as an adjunct to basal insulin on markers of cardiovascular risk in patients with type 2 diabetes. Curr Med Res Opin, 24:79-85. 